\title{
Envelhecimento populacional no Brasil: uma realidade nova.
}

\author{
Alexandre Kalache
}

Os fatores determinantes do envelhecimento, a nivel da população de um país, são, fundamentalmente, ditados pelo comportamento de suas taxas de fertilidade e, de modo menos importante, de suas taxas de mortalidade. Para que uma população envelheça, é necessário, primeiro, que haja uma queda da fertilidade; um menor ingresso de crianças na população faz com que a proporção de jovens, na mesma, diminua. Se, simultanea ou posteriormente, há também uma redução das taxas de mortalidade (fazendo com que a expectativa de vida da população, como um todo, torne-se maior), o processo de envelhecimento de tal população torna-se ainda mais acentuado. Tal processo é dinâmico, estabelece-se em etapas sucessivas e é. comumente, conhe cido como "transição epidemiológica ou demográfica". Na sua etapa inicial, as taxas de fertilidade são altas e a mortalidade está concentrada nos segmentos mais jovens da população: progressivamente, as taxas de mortalidade decrescem, aumentando a percentagem de crianças e prolongando a sobrevida, enquanto as taxas de fertilidade diminuem - fazendo com que, proporctonalmente, os grupos de mais idade aumentem em relação aos mais jovens. Finalmente, quando as taxas de fertilidade e de mortalidade se mantên baixas, há um progressivo aumento, na proporção de adultos. na população. incluındo, naturalmente, os mais idosos. Neste estágio da transição epidemiológica, a "pirâmide" populacional passa a apresentar uma configuração retangularizada, característica das populações curopéias de hoje, por exemplo.

O Brasil está em franco processo de envelhecimento, tendo já atravessado as etapas iniciais do processo de transição epidemiológica e me smo (no caso de algumas áreas localizadas de regioes metropolitanas ma is desenvolvidas) atingido seu estágio final. Até a década de 50 ou mesmo 60, as características demográficas do país indicavam uma populaza o bastante jovem. com altas taxas de fertilidade e taxas de mortalidade que apenas começavam a diminuir. A par tır de então, teve início um processo de redução das taxas de fertilidade que, nos últimos anos, vem se acelerando. Para - País. como um todo, as taxas de fertilidade diminuíram em cerca de $30 \%$, entre 1970 e 1980 , diminuição esta, que se verificou em todas as regizes do Brasil, tanto nas zonas 
urbanas como nas rurais. Dados mais recentes, para algumas áreas do país, mostram que a redução das taxas de fertilidade, provavelmente, se acentuou deste então; a taxa de fecundidade total para o Estado de São Paulo, em 1980, era de 3.4 (número médio de filhos, por mulher em idade

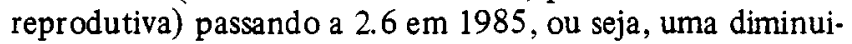
ção de $20 \%$, em apenas 5 anos. Paralelamente, tem havido uma diminuição nas taxas brutas de mortalidade para 0 País, como um todo, desde o início deste século, particularmente, a partir da década de 40 . Como conseqüência, a expectativa de vida, ao nascer - que era de apenas 33.7 anos em 1900 - havia alcançado 43.2 anos em 1950, 55.0 em 1960, 57.1 em 1970 e 63.5 anos em 1980. As estima tivas indicam que, atualmente, ela deve ser da ordem de 66 anos, devendo alcançar 68.6 anos no ano 2000 e ultrapassar 72 no ano 2020 .

Este processo de rápido envelhecimen to populacional não é, naturalmente, uma característica única do Brasil, sendo compartilhado, de modo mais ou menos acentuado, por diversos outros países em desenvolvimento. Desta maneira, o envelhecimento populacional, que caracteriza, hoje, as populações dos países industrializados, passará, em futuro breve, a ser uma característica também nossa. $\mathrm{Na}$ verdade, já hoje, a maioria das pessoas idosas vive em países não-desenvolvidos e dentro de poucos anos, na passagem do século, mais de três quartos daqueles, com mais de 60 anos, serão habitantes do Terceiro Mundo.

Há, no entanto, uma diferença fundamental entre os fatores que levaram a transição epidemiológica dos países mais desenvolvidos e aqueles que se observam, hoje, nos países subdesenvolvidos. Até a Segunda Guerra Mundial, o impacto médico-tecnológico, na redução da mortalidade, estava limitado a um mínimo. Foi só a partir daí que se tornou possível prevenir e tratar diversas enfermidades, cujo desfecho, anteriormente, era, freqüentemente, fa tal: tuberculose, poliomielite, sarampo, gastroenterites e pneumopatias na infância entre muitas outras. No entanto, muito antes disso, a expectativa de vida na Europa, como exemplo, já havia alcançado valores tão altos como os do Brasil de agora. Isso se deveu a uma melhoria das condições de vida para as populações daquele continente como um todo: melhor nutrição, condições habitacionais, saneamento, etc. Atualmente, mesmo que as condições de vida, sob o ponto de vista sócio-econômico, não tenham melhorado, significativamente, para uma parcela apreciável da população dos países subdesenvolvidos, as taxas de mortalidade vêm experimentando substanciais diminuições. Elas são resultantes de in tervenções, de medidas específicas de saúde pública, do tratamento efe tivo de infecções; não é por tanto 
o processo de "envelhecimento na tural" como conseqüência de melhores níveis de vida para a maioria dos habitantes (como na Europa pós-Revolução Industrial), mas um pro cesso "artificial", em que muitos sobrevivem, apesar de suas" condiçôes de vida, simplesmente, porque recebem imunização ativa contra determinadas doenças ou tratamento específico, para outras. Em termos práticos, este tipo de processo de envelhecimento defron ta países como.o Brasil, com um duplo encargo na área da saúde : por um lad o a importância crescente de doenças crôniças entre as causas de mortalidade (desde o início da década de 60 que as doenças cardiovasculares passaram a ser o primeiro grupo entre as causas de mortes no Brasil, seguido, atualmen te, por neoplasias). Por outro lado, as marcas do subdesenvolvimente permanecem presentes, sobretudo, em termos de morbidade por doenças infecciosas e parasitárias ou pela importância que a subnutrição continua ocupando entre nós.

O envelhecimento da população brasileira é um fato irreversível, e que deverá se acentuar, no futuro próximo imediato. O impacto desta nova "ordem demográfica" é imenso - sobretudo, quando se observa que os fatores associados ao subdesenvolvimen to continuarão se manifestando por um tempo difícil de ser definido. Nã̃o estamos, portanto, diante de uma situaçẫo como a européia; quando o envelhecimento de suas populaçōes ocorreu, a maioria dos países europeus já apresentava níveis sócio-econômicos que proporcionavam, a grande parte de suas populações, condiçōes de vida satisfatórias. Com isso, os problemas conseqủentes ao envelhecimento populacional puderam ser encarados como prioritários. Nem por isso tem sido fácil resolvê-los. O desafio para nós é, portanto, considerável. $\mathrm{O}$ envelhecimento de nossa população está se processando em meio a condições de vida, para parcelas imensas da população, ainda muito desfavoráveis. O id oso nãoé uma prioridade, como pode ser visto nos países industrializados. No entanto, eles estão aí para ficar - e em proporções crescentes, passando de $6 \%$ da população, em 1980, para mais de $13 \%$ previstos para o início do Século XXI.

A natureza dos problemas médico-sociais dos idosos tem características específicas que acentuam a importância de trabalhá-los, cuidadosa e sistematicamente. É muito mais fácil ignorar os problemas da infância - pois eles "desaparecem" do seio da comunidade, com a mesma ra. pidez como surgiram - do que muitos dos problemas associados à velhice. Por exemplo, uma criança com gastroenterite é mais facilmente ignorada pelo sistema de sáude, uma vez que o desfecho é dramático: cura ou morte em poucos dias. No entanto, uma pessoa idosa que sofra um acidente vascular-cerebral, ou tenha diabetes, ou seja hiper- 
tensa, permanecerá na comunidade, requerendo cuidados de saúde, não por dias ou semanas - mas sim, por anos. Cedo ou tarde suas necessida des serão reconhecidas e algum tipo de intervenção, realizado. O resultado inevitável é uma competição por (escassos) recursos. $\mathrm{E}$ o único encaminhamento satisfa tório é o reconhecimento desta nova realidade demográfica, de modo a quē ūm planejamento adequado possa ser feito.

O envelhecimento da população brasileira necessita, de imediato, de um diagnóstico de saúde a niveis nacional e regional, que possa conduzir a propostas realistas. As intervenções que daí surgirem, deverão então, ser avaliadas e redirigidas. Há uma necessidade premente de métodos inovadores e imagina tivos, que possam contribuir para uma a tenção ao idoso, em bases humanísticas e, ao mesmo tempo, compatíveis com a realidade sócio-econômica do país. $O$ obje tivo final deve ser sempre a manutenção, na comunidade, do maior número possivel de idosos, contribuindo, ativamente, para ela, e mantendo seu grau de autonomia (e dignidade) pelo maior tempo possivel. Este debate se impõe, de imediato, para quantos possam estar interessados em Saúde Pública, em nosso país. 